\title{
Evaluation of the cranial base and sella turcica morphology in patients with unilateral cleft lip and palate
}

\author{
Nehir Canıgür Bavbek (iD, " Fatma Tekin Kaymaz, \\ Çağrı Türköz iD \\ Department of Orthodontics, Faculty of Dentistry, \\ Gazi University, Ankara, Turkey
}

\begin{abstract}
ObJective: The aim of this study was to investigate the size and morphology of the sella turcica and cranial base in individuals with unilateral cleft lip and palate (UCLP), and to compare it with individuals showing Class III discrepancy due to maxillary deficiency (CL3) and with individuals having normal (CL1) craniofacial development.
\end{abstract}

Materials and METHOD: This retrospective study was carried out on the lateral cephalogram tracings of UCLP (10 females, 4 males; $12.05 \pm 1.14$ years), CL3 (10 females, 5 males; $11.73 \pm 0.89$ years) and CL1 ( 10 females, 5 males; $13.11 \pm 1.11$ years) patients. Linear and angular measurements related to sella turcica and cranial base were performed. Intergroup comparisons were either made with one-way ANOVA followed by Tukey's test or with Kruskal-Wallis test with Bonferroni adjustment $(p<0.05)$. Spearman correlation coefficient was used for correlations $(p<0.01)$.

RESULTS: The length of the maxilla (Co-A) was shorter in UCLP $(p=0.035)$ and CL3 $(p=0.001)$ than in CL1. Total cranial length (Ba-N) was greater in UCLP than in CL3 $(p=0.012)$ and $C L 1(p=0.016)$. Cranial base angle $\left(N-S-A r^{\circ}\right)$ was less in CL3 than in UCLP $(p=0.001)$ and CL1 $(p=0.009)$. $B a-N(p=0.003)$ and anterior cranial length $(S-N)(p=0.000)$ were positively correlated with Co-A. Posterior cranial length (S-Ba) was positively correlated with ramus height (Ar-Go) $(p=0.001)$. The diameter of sella was bigger in CL1 than in CL3 $(p=0.025)$. The prevalence of morphologic variations of sella turcica in UCLP was higher $(71.4 \%)$ than in control groups.

Conclusion: Although there was a Class III tendency in UCLP due to maxillary deficiency, cranial base flexure characteristic to CL3 anomalies was not seen in this group. The existence of UCLP or CL3 did not alter dimensions of sella turcica, but morphologic variations were more common in UCLP.

Received: Dec 7, 2018; Accepted: March 20, 2019

*Corresponding author: Dr. Nehir Canıgür Bavbek, Department of

Orthodontics, Faculty of Dentistry, Gazi University, 8. Cadde, 82. Sokak,

06510, Emek, Ankara, Turkey;

E-mail: ncanigur@yahoo.com
KEYwORDS: Cleft lip; cleft palate; cranial base; sella turcica; malocclusion, Angle Class III

Citatıon: Canıgür Bavbek N, Tekin Kaymaz F, Türköz Ç. Evaluation of the cranial base and sella turcica morphology in patients with unilateral cleft lip and palate. Acta Odontol Turc 2019;36(2):33-40

EdıToR: Güven Kayaoğlu, Gazi University, Ankara, Turkey

Copyright: (c) 2019 Canıgür Bavbek et al. This work is licensed under a Creative Commons Attribution License. Unrestricted use, distribution and reproduction in any medium is permitted provided the original author and source are credited.

FundING: None declared.

CONFLICT OF INTEREST: The authors declare no conflict of interest related to this study.

\section{INTRODUCTION}

Cranial base and sella turcica are the most commonly used cephalometric structures for orthodontic diagnosis and they are known to be closely related to the development of maxillomandibular complex and malocclusions. ${ }^{1}$ Anterior (sella to nasion points) and posterior parts (sella to basion points) of the cranial base coincide in the sella point (S) and form a flexion, which is defined as cranial base angle and measured between nasion-sella and basion (or articulare) points in lateral cephalometric radiographs. ${ }^{2}$

The cranial base angle and length may be associated with the growth direction of facial bones and contribute to facial projection. Abnormalities of the posterior and anterior cranial base are generally related to mandibular prognathism and retrusive maxilla, respectively. Class III anomalies may be due to retrognathic maxilla, prognathic mandible or a combination of both. Previous studies showed that Class III patients had a smaller cranial base angle and shorter cranial base lengths than Class I patients. ${ }^{3}$ However, as Proff et al. ${ }^{2}$ stated, these findings were commonly used to explain the developmental aspect of Class III due to mandibular prognathism but the relationship between cranial base and maxillary development still remains unclear.

While counting on the contribution of cranial base morphology to development of craniofacial complex, 
it would be wise to think that the anatomical center of cranial base, the sella turcica would also be an important region of development. Anterior part of sella turcica develops from neural crest cells whereas posterior part develops from paraxial mesoderm, which is in close relation to notochord. ${ }^{4}$ Due to its position and embryologic origin, the development of sella turcica and the changes and pathologies in its size and morphology have been associated with many different anomalies and syndromes like spina bifida, ${ }^{5}$ velocardiofacial syndrome, ${ }^{6}$ Williams syndrome, ${ }^{7}$ Down syndrome, ${ }^{8}$ cleft lip and palate, ${ }^{9-12}$ and orthodontic malocclusions such as Class III. ${ }^{13}$

Cleft lip and palate result from the inadequate fusion of embryonic extensions that produce the soft tissues and bones, which make up the upper jaw and the roof of the mouth. While developmental anomalies causing cleft lip show their effects at 4-7 weeks of gestation, the effects are seen at 7-12 weeks of gestation in cleft palate. ${ }^{14,15}$ The incidence of cleft lip and palate is approximately $1 / 700$, ranging between $1 / 500$ to $1 / 2,500$ with wide variation among geographic regions. ${ }^{16,17}$ Clefts can be categorized as cleft lip (CL), cleft palate (CP), unilateral cleft lip and palate (UCLP) and bilateral cleft lip and palate (BCLP), according to the affected region. ${ }^{18}$ With a prevalence of approximately $30 \%$, UCLP is the most commonly seen cleft type among all categories and generally has a tendency to present Class III malocclusion. ${ }^{19}$ Ozturk and Cura ${ }^{20}$ reported that in patients with UCLP, maxilla was more retrognathic and posteriorly inclined, which could be the result of either scar contracture and palatal muscle strain due to surgeries, developmental problems in maxilla or a combination of both. ${ }^{21}$ Cranial base ${ }^{22}$ and sella turcica ${ }^{9-11}$ region were also affected in these subjects and that is why Harris ${ }^{22}$ underlined that CLP should not only be named as a syndrome related to jaws, rather it should be seen as a general growth disturbance. It is therefore important to understand and diagnose the morphology of the craniofacial complex in patients with UCLP to predict facial development in such individuals.

Although there are similarities between reported changes regarding the cranial base and sella turcica, developmental aspects of UCLP and Class III malocclusions may vary. Heredity is known to be the general cause of non-syndromic Class III malocclusions while Class III malocclusion in UCLP may be a result of a multi-factorial sequence including heredity and surgery as indicated previously. ${ }^{20,21}$ In order to understand the etiology of Class III development in UCLP, it is important to analyze how they differentiate from non-syndromic Class III patients. There are only three studies comparing these two patient groups; two of them evaluate the skeletal features with some limitations, and one of them reports results based on only soft tissue parameters, while none of them analyzes sella turcica region in detail. ${ }^{21,23,24}$

Therefore, the purpose of this study was to evaluate the size and morphology of the sella turcica together with

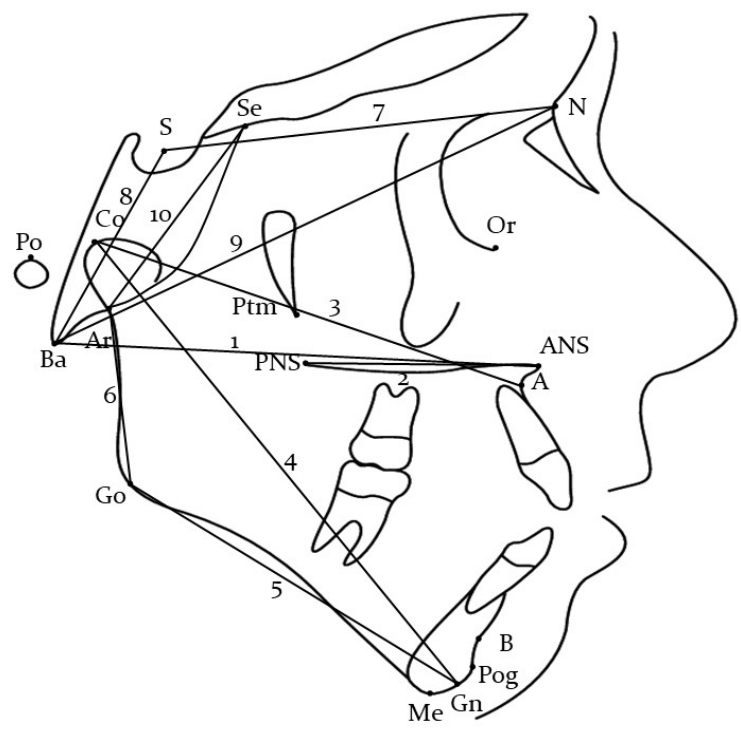

Figure 1. Linear measurements performed in this study; 1: distance between Basion and Anterior Nasal Spine (Ba-ANS), 2: distance between Anterior Nasal Spine and Posterior Nasal Spine (ANS-PNS), 3: distance between Condylion and $A$ point (Co-A), 4: distance between Condylion and Gnathion (Co-Gn), 5: distance between Gonion and Gnathion (Go-Gn), 6: distance between Articulare and Gonion (Ar-Go), 7: distance between Sella and Nasion (S-N), 8: distance between Sella and Basion (S-Ba), 9: distance between Basion and Nasion (Ba-N), 10: distance between Articulare and Se point (Ar-Se)

the cranial base morphology in individuals with UCLP, and to compare it with individuals showing Class III discrepancy due to maxillary deficiency and individuals with normal Class I craniofacial development. The hypothesis was that the size and morphology of the cranial base and sella turcica of patients with UCLP and skeletal Class III were similar, but they showed differences from the skeletal Class I development pattern.

\section{Materials ANd Method}

This retrospective cross-sectional radiologic study included the lateral cephalograms of a total of 44 patients within the 11-14 age range who were previously treated in the Department of Orthodontics of the Faculty of Dentistry at Gazi University, Ankara, Turkey. The ethical approval was obtained from the ethical committee of the same university (77082166604.03.06) before conducting the study.

The study was carried out on three groups; 14 patients (10 females, 4 males; mean chronological age $12.05 \pm 1.14$ years) with unilateral cleft lip and palate (UCLP) that served as the study group, 15 patients (10 females, 5 males; mean chronological age $11.73 \pm 0.89$ years) with skeletal class III anomaly (CL3) and 15 patients (10 females, 5 males; mean chronological age $13.11 \pm 1.11$ years) with skeletal Class I craniofacial morphology (CL1) that served as Class III and Class I control groups, respectively.

Main inclusion criteria for all groups were as follows: having a good-quality pre-treatment lateral 


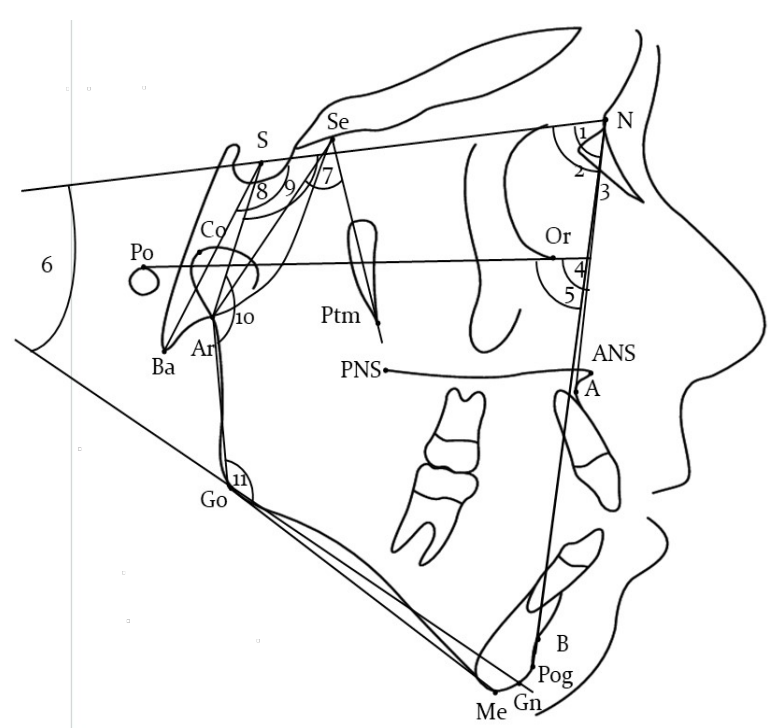

Figure 2. Angular measurements performed in this study; 1: angle between Sella, Nasion and $A$ point $\left(S N A^{\circ}\right), 2$ : angle between Sella, Nasion and $B$ point $\left(S N B^{\circ}\right)$, 3: angle between $A$ point, Nasion and $B$ point $\left(A N B^{\circ}\right), 4$ : angle between Frankfurt Horizontal Line and $N-A$ line $\left(F H / N A^{\circ}\right)$, 5: angle between Frankfurt Horizontal Line and N-Pog line $\left(\mathrm{FH} / \mathrm{NPog}{ }^{\circ}\right)$, 6: angle between S-N Line and Go-Gn line (SN/GoGn $)$, 7: angle between Articulare, Se and Ptm points $\left(\mathrm{Ar}-\mathrm{Se}-\mathrm{Ptm}{ }^{\circ}\right.$ ), 8: angle between Nasion, Sella and Basion points (N-S$\left.B a^{\circ}\right)$, 9: angle between Nasion, Sella and Articulare points (N-S-Ar ${ }^{\circ}$, 10: angle between Sella, Articulare and Gonion points $\left(S-A r-G 0^{\circ}\right)$, 11: angle between Articulare, Gonion and Menton points (Ar-Go-Me $\left.{ }^{\circ}\right)$

cephalometric radiograph, no other systemic or chronic diseases such as abnormalities of the pituitary gland and acromegaly affecting the size and morphology of the sella turcica, no previous history of orthodontic treatment, no craniofacial anomalies in Class III and Class I groups, and no other syndrome history in UCLP patients.

All UCLP patients had been operated at an early age for lip and palatal closure but none of them had undergone orthodontic treatment yet. Patients with skeletal Class III anomaly $\left(\mathrm{ANB}<0^{\circ}\right)$ due to maxillary retrognathia $\left(\mathrm{SNA}<82^{\circ}\right)$ with optimum vertical growth pattern (SN/GoGN: $32 \pm 6^{\circ}$ ) and Angle Class III dental relationship were selected for CL3 control group. On the other hand, ideal sagittal (ANB: $2 \pm 2^{\circ}$ ) and vertical (SN/GoGn: $32 \pm 6^{\circ}$ ) craniofacial development, Angle Class I dental relationship, ideal overjet and overbite, mild crowding (less than 3-4 mm) with no impacted tooth were set as the criteria for CL1 control group.

Measurements defining the size and morphology of sella turcica and cranial base were performed on manual tracings of patients' radiographs on acetate paper. The magnification ratio was 1:1.1 and all linear measurements were corrected for magnification prior to the statistical analysis. Same researcher (F.T.K.) did all the measurements.

The linear and angular measurements performed in this study are shown in Figures 1 and 2, respectively. The dimensions of sella turcica were measured according to Silverman ${ }^{25}$ (Figure 3 ). and sella turcica morphology was defined according to the definitions of Axelsson et al. ${ }^{26}$ and categorized as: normal sella turcica, oblique anterior wall, double contour of the floor, sella turcica bridge, irregularity in the posterior part of the sella turcica and pyramidal shape of the dorsum sellae (Figure 4).

\section{Statistical analysis}

Data from all measurements were transferred to a statistical program (SPSS, 16.0, IBM Corp., Armonk, NY, USA). The Shapiro-Wilk test was used to determine whether the data showed a normal distribution. If the data were normally distributed, Tukey's test was used after one-way ANOVA and if not, the Kruskal-Wallis test with Bonferroni adjustment was used. Tests were performed with a significance level of 0.05 . Spearman correlation analysis was used to evaluate the correlations at the significance level of 0.01 .

\section{Results}

The mean and standard deviations of all measurements and intergroup comparisons are presented in Table 1.

\section{General craniofacial morphology}

Length of maxilla (Co-A) was smaller in UCLP and CL3 than in CL1. When compared to UCLP, mandible was more anteriorly positioned in sagittal plane $\left(\mathrm{SNB}^{\circ}, \mathrm{FH}-\right.$ $\mathrm{NPg}^{\circ}$ ) and ramus was more posteriorly inclined (S-Ar$\mathrm{Go}^{\circ}$ ) in CL3. Ramus length (Ar-Go) was found to be decreased in CL3 than in UCLP and CL1. As a result of these differences, maxillo-mandibular relationship according to anterior cranial base $\left(\mathrm{ANB}^{\circ}\right)$ showed significant difference in CL3 when compared to CL1 $(p<0.05)$.

\section{Cranial base morphology}

Total cranial length (Ba-N) was found to be increased in UCLP than in CL3 and CL1. Anterior cranial base length (S-N) was shorter in CL3 than in CL1. Cranial base angle (N-S-Ar ${ }^{\circ}$ was found to be decreased in CL3 than in UCLP and CL1. Middle cranial base angle (Ar$\mathrm{Se}-\mathrm{Pm}^{\circ}$ ) was significantly smaller in CL3 group than in CL1 group $(p<0.05)$.

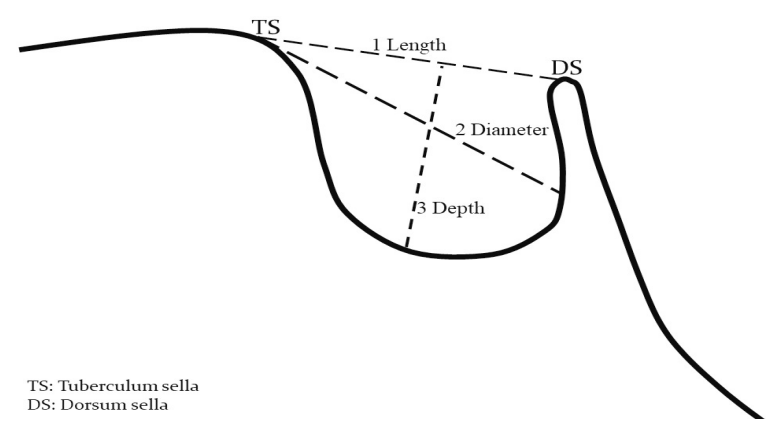

Figure 3. Dimensions of sella turcica (TS: tuberculum sella, DS: dorsum sella) 

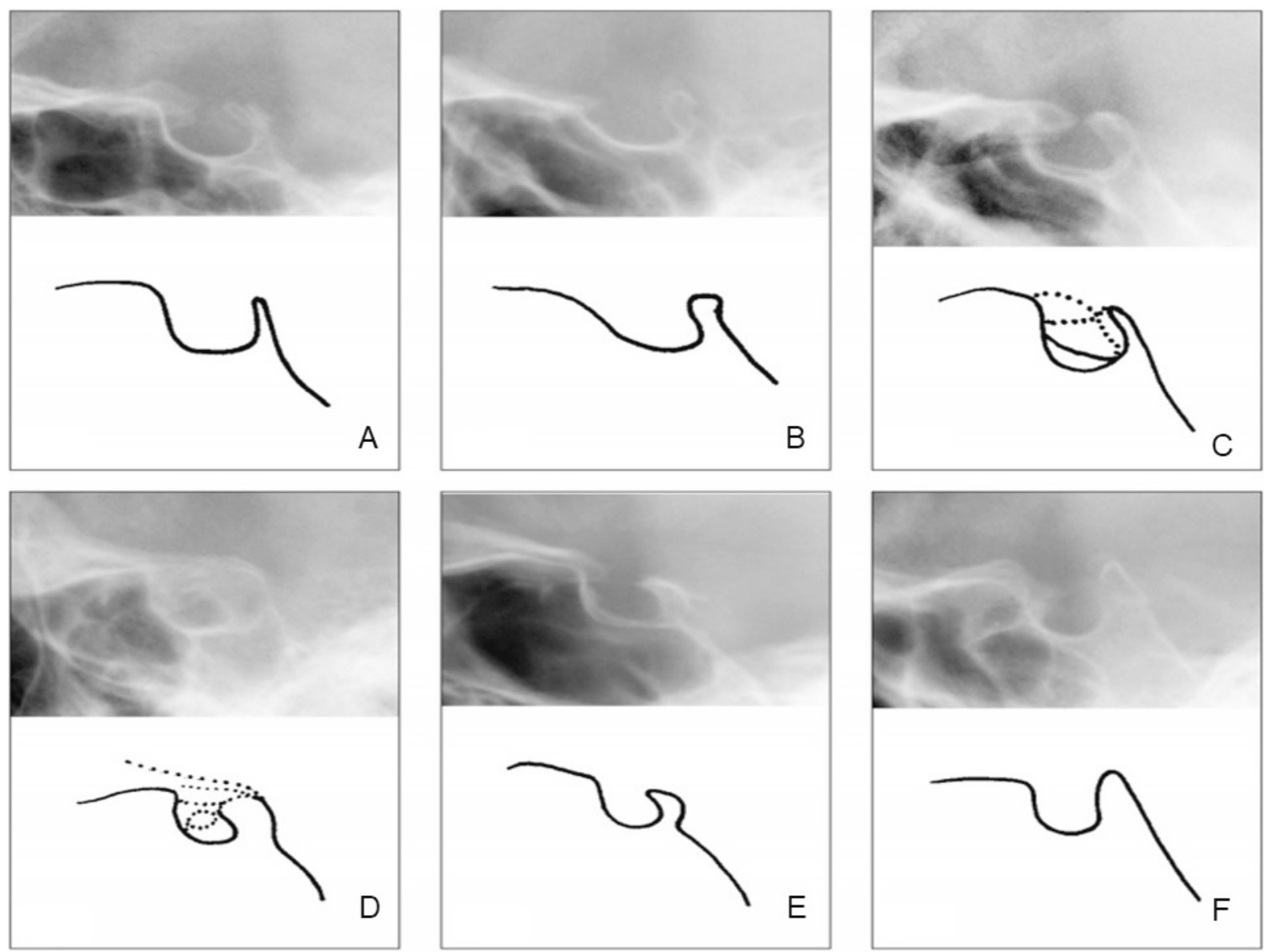

Figure 4. Morphologic variations of sella turcica classified according to Axelsson et al.26; (A) normal sella turcica, (B) oblique anterior wall, (C) double contour of the floor, (D) sella turcica bridge, $(E)$ irregularity in the posterior part of the sella turcica, $(F)$ pyramidal shape of the dorsum sella

\section{Correlations}

Total cranial base length (Ba-N) was positively correlated with dimensions (ANS-PNS, $r=0.526, p=0.000$; Co-A, $r=$ $0.441, p=0.003$ ) and sagittal position of maxilla (Ba-ANS, $r=0.558, p=0.000)$. Posterior cranial length $(S-B a)$ was positively correlated with ramus height (Ar-Go, $r=0.480$, $\mathrm{p}=0.001)$ and anterior cranial length ( $\mathrm{S}-\mathrm{N}$ ) was positively correlated with dimension of maxilla (Co-A, $r=0.599$, $\mathrm{p}=0.000)$. Sagittal position of mandible $\left(\mathrm{SNB}^{\circ}, \mathrm{r}=-0.519\right.$, $\mathrm{p}=0.000)$ and rotation of mandible $\left(\mathrm{S}-\mathrm{Ar}-\mathrm{Go}^{\circ}, \mathrm{r}=-0.556\right.$, $\mathrm{p}=0.000$ ) were negatively correlated with cranial base angle (N-S-Ar ${ }^{\circ}$.

\section{Sella turcica}

When comparing linear dimensions (length, diameter and depth) of sella turcica, no significant differences were found between study groups except that the diameter of sella was higher in CL1 group than in CL3 group ( $p<0.05$; Table 2$)$.

The distribution of morphological variations of sella turcica in UCLP, CL3 and CL1 groups are presented in Table 3. All groups showed some morphological variations in sella turcica, but the prevalence in UCLP (71.4\%) was much higher than in CL3 (33.4\%) and CL1 (26.7\%) control groups, respectively.

\section{Discussion}

This study was conducted based on the hypothesis that UCLP and Class III discrepancy due to maxillary retrognathia would show a similar cranial base and sella turcica morphology and would differ from skeletally Class I patients. The reason behind this hypothesis was to understand the Class III tendency in UCLP patients and how cranial base or sella turcica region were involved in this scenario. However, based on our findings, this hypothesis was rejected.

Many authors have argued about the relationship between the development of cranial base and dentofacial features. ${ }^{27,28}$ Due to differences in articulation of maxilla and mandible with the cranial base, growth and orientation variations of the cranial base may result in differential alterations in the position of the jaws, which would have an impact on the occlusion. ${ }^{29}$ It was reported that the anterior cranial base contributes to the growth of the upper and middle parts of the face, ${ }^{30-32}$ and that is why its development was inadequate in Class III anomalies originating from maxillary deficiency. ${ }^{4}$ Our findings also showed similarities with previous literature indicating that Class III patients with retrognathic maxilla had smaller anterior cranial base length (S-N) and they 


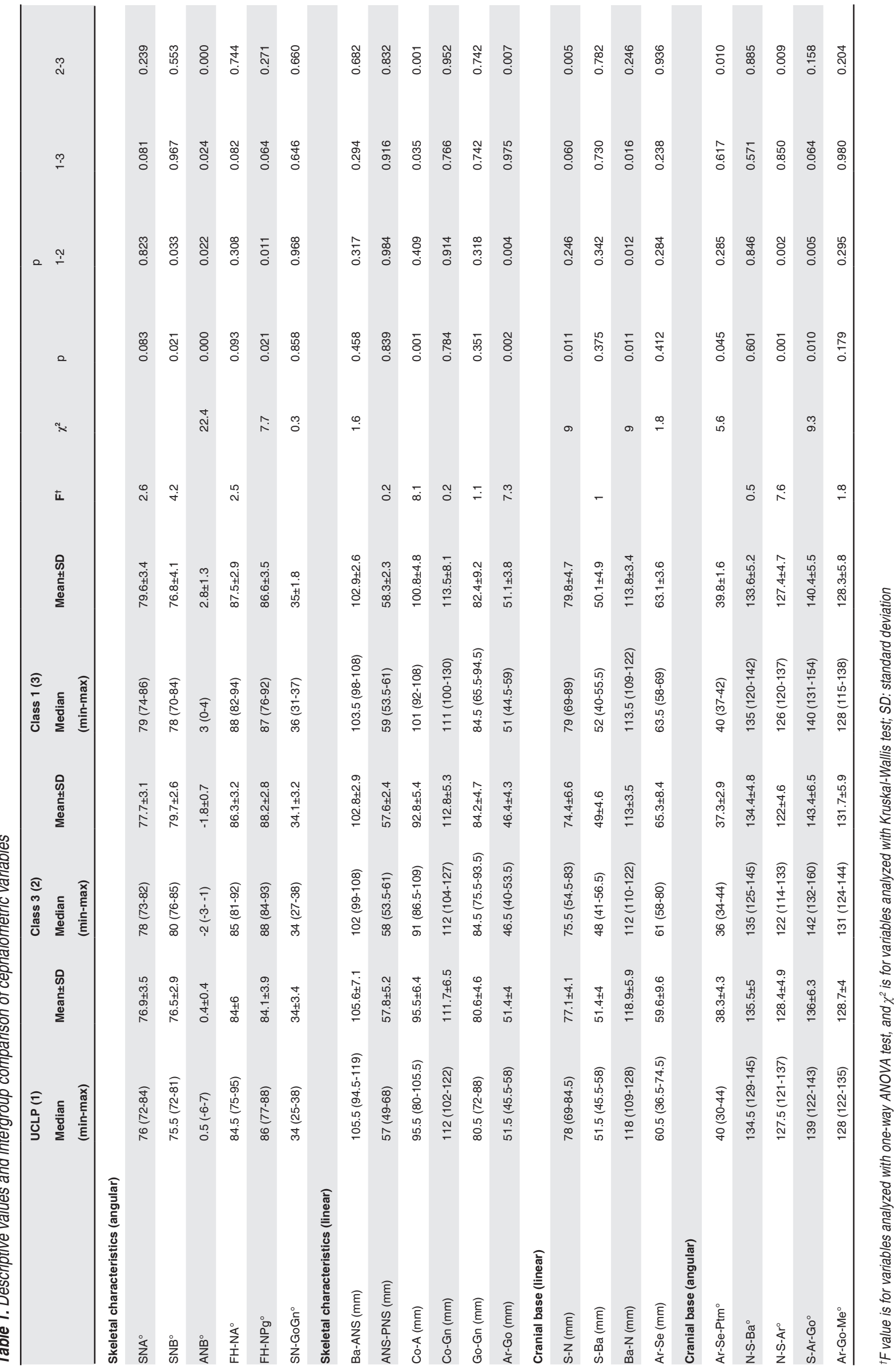


Table 2. Intergroup comparison of dimensions of sella turcica

\begin{tabular}{|c|c|c|c|c|c|c|c|c|c|c|c|}
\hline & \multicolumn{2}{|l|}{ UCLP (1) } & \multicolumn{2}{|l|}{ Class $3(2)$} & \multicolumn{4}{|l|}{ Class $1(3)$} & \multicolumn{3}{|l|}{$\mathbf{p}$} \\
\hline & Median (min-max) & Mean \pm SD & Median (min-max) & Mean \pm SD & Median (min-max) & Mean \pm SD & $\mathbf{F}^{\dagger}$ & $\mathbf{p}$ & $1-2$ & $1-3$ & $2-3$ \\
\hline Length (mm) & $12(11-15.5)$ & $12.69 \pm 1.35$ & $11(9-16.5)$ & $11.74 \pm 1.87$ & $12(10-19)$ & $13.03 \pm 2.33$ & 1.8 & 0.171 & 0.379 & 0.882 & 0.164 \\
\hline Diameter $(\mathrm{mm})$ & $14(10-18)$ & $13.76 \pm 2.12$ & $13.5(11-15.5)$ & $13.22 \pm 1.44$ & $15.5(12-20)$ & $15 \pm 1.95$ & 3.9 & 0.028 & 0.709 & 0.155 & 0.025 \\
\hline Depth (mm) & $9(6.5-11.5)$ & $9.08 \pm 1.31$ & $9(5.5-12)$ & $9 \pm 1.61$ & $10(8-12)$ & $9.96 \pm 1.26$ & 2.1 & 0.133 & 0.985 & 0.229 & 0.161 \\
\hline
\end{tabular}

${ }^{\dagger} F$ value is for variables analyzed with one-way ANOVA test; SD: standard deviation

Table 3. Distribution of morphologic variations among UCLP, CL3 and CL1 groups

\begin{tabular}{|c|c|c|c|c|c|c|}
\hline & \multicolumn{2}{|c|}{ UCLP } & \multicolumn{2}{|c|}{ Class 3} & \multicolumn{2}{|c|}{ Class 1} \\
\hline & n & $\%$ & n & $\%$ & $\mathbf{n}$ & $\%$ \\
\hline Normal & 4 & 28.6 & 10 & 66.6 & 11 & 73.3 \\
\hline Bridging & 4 & 28.6 & 1 & 6.7 & 0 & 0 \\
\hline Pyramidal & 3 & 21.4 & 2 & 13.3 & 2 & 13.3 \\
\hline Oblique anterior wall & 1 & 7.1 & 1 & 6.7 & 1 & 6.7 \\
\hline Double contour & 2 & 14.3 & 1 & 6.7 & 1 & 6.7 \\
\hline
\end{tabular}

had a greater flexure of the cranial base $\left(\mathrm{N}-\mathrm{S}-\mathrm{Ar}^{\circ}\right)$. Besides, significant correlations were found between cranial lengths and maxilla and mandible pointing out to the formation of Class III. However, this differential pattern in cranial base was not observed in UCLP, unlike what we stated in our hypothesis and there were no statistically significant differences between neither CL1 nor CL3 control groups. Our findings are in accordance with previous study results, ${ }^{21,23,33}$ and may be interpreted as scars due to surgical repairs are also important for the retrusive maxilla and Class III malocclusion tendency in UCLP patients and the influence of cranial base development remains unclear. This hypothesis might also be supported by Lin et al. ${ }^{21}$ who found no difference between non-syndromic CL3 patients and UCLP patients in cranial base measurements although maxilla was more retrusive in UCLP patients.

Sella turcica is an important region for orthodontic practice since it is used to determine the sella point; the geometrical center of sella turcica, which is widely used in orthodontic analysis made on lateral cephalometric tracings. ${ }^{34}$ However, as it hosts pituitary gland and has an embryologic origin very closely related to craniofacial development, changes in dimensions and morphology of sella turcica were associated with many disorders including CLP ${ }^{4}$ and malocclusions as Class III. ${ }^{13,35}$ In our study, no significant differences were found between groups except that the diameter of sella turcica was larger in Class I individuals than in Class III. This finding was contradictory to the findings of previous literature showing either no effect of skeletal discrepancy on sella dimensions ${ }^{36}$ or increased dimensions in Class III subjects when compared to Class I. ${ }^{13,35}$ The differences between our findings and previous studies might be due to individuals included in the study groups since changes in dimensions of sella turcica were also reported to vary based on demographic factors such as age and gender. ${ }^{34}$ For this reason, morphological variations of sella turcica were found to be more related to developmental and genetic disorders of craniofacial region.

In terms of sella turcica morphology, UCLP patients had more morphologic variations (71.4\%) when compared to both control groups (CL3: $33.4 \%$ and CL1: $26.7 \%)$ Previously published data showed that morphologic diversities can be frequent in healthy people as well. Nevertheless, Shah et al. ${ }^{37}$ and Alkofide $^{38}$ reported that $66.1 \%$ and $66.7 \%$ of healthy subjects, respectively, had a normal sella turcica morphology, which is parallel to our study results. The increased prevalence of morphological deviations in UCLP in our study was also reported by Molsted et al. ${ }^{6}$ and Sundareswaran \& Nipun, ${ }^{39}$ and normal morphology of sella turcica was significantly less common in UCLP patients $(28.6 \%)$. The relationship between sella turcica morphology and CLP might be due to the same embryologic origin of sella turcica and hard palate, the notochord, and the defective proliferation and unguided migration of neural crest cells during craniofacial development. ${ }^{6,39}$

Our limitations in this study were the retrospective design, small sample size and non-homogeneous gender distribution in our groups. In addition, UCLP group could not be completely standardized with respect to their skeletal pattern since we had a limited number of subjects to analyze. While constructing the Class III control group we specifically selected Class III patients with maxillary retrognathia, but our findings still addressed the contribution of mandibular prognathism in Class III relationship, which indicated that maxillary deficiency was not the only reason of the skeletal problem. Together with the aforementioned problems, it would have added value to our manuscript to use 
3D data since it would eliminate the problems related to magnification, distortion and overlapping images. However, due to the retrospective nature of the study and risk/benefit ratio of acquiring 3D images from every patient, only lateral cephalometric radiographs were used in this study. Thus, a further study conducted on 3D data with larger sample size and equal gender distribution is necessary to get more insight about cranial base development and occurrence of cleft lip and palate.

\section{CONCLUSION}

The findings of our study showed that there were no major differences between UCLP and the control groups (CL1 and CL3) with regard to cranial base morphology. However, cranial base flexure characteristic to Class III anomalies was not seen in UCLP. Morphologic variations of sella turcica were also more common in UCLP.

\section{ACKNOWLEDGEMENT}

This study was presented as an oral presentation at the $105^{\text {th }}$ FDI World Dental Federation Congress, August 29 September 1, 2017, Madrid, Spain.

\section{References}

1. Enlow DH, McNamara JA Jr. The neurocranial basis for facial form and pattern. Angle Orthod 1973;43:256-70.

2. Proff $P$, Will F, Bokan I, Fanghanel J, Gedrange T. Cranial base features in skeletal Class III patients. Angle Orthod 2008;78:433-9.

3. Singh GD, McNamara JA Jr, Lozanoff S. Morphometry of the cranial base in subjects with Class III malocclusion. J Dent Res 1997;76:694703.

4. Kjaer I. Orthodontics and foetal pathology: a personal view on craniofacial patterning. Eur J Orthod 2010;32:140-7.

5. Kjaer I, Hansen BF, Keeling JW. Axial skeleton and pituitary gland in human fetuses with spina bifida and cranial encephalocele. Pediatr Pathol Lab Med 1996;16:909-26.

6. Molsted K, Boers M, Kjaer I. The morphology of the sella turcica in velocardiofacial syndrome suggests involvement of a neural crest developmental field. Am J Med Genet A 2010;152A:1450-7.

7. Axelsson S, Storhaug K, Kjaer I. Post-natal size and morphology of the sella turcica in Williams syndrome. Eur J Orthod 2004;26:613-21.

8. Russell BG, Kjaer I. Postnatal structure of the sella turcica in Down syndrome. Am J Med Genet 1999;87:183-8.

9. Molsted K, Kjaer I, Dahl E. Spheno-occipital synchondrosis in threemonth-old children with clefts of the lip and palate: a radiographic study. Cleft Palate Craniofac J 1993;30:569-73.

10. Kjaer I, Reintoft I, Poulsen H, Nolting D, Prause JU, Jensen OA, et al. A new craniofacial disorder involving hypertelorism and malformations of external nose, palate and pituitary gland. J Craniofac Genet Dev Biol 1997;17:23-34.

11. Nielsen BW, Molsted K, Kjaer I. Maxillary and sella turcica morphology in newborns with cleft lip and palate. Cleft Palate Craniofac J 2005;42:610-7.

12. Nielsen BW, Molsted K, Skovgaard LT, Kjaer I. Cross-sectional study of the length of the nasal bone in cleft lip and palate subjects. Cleft Palate Craniofac J 2005;42:417-22.

13. Alkofide EA. The shape and size of the sella turcica in skeletal Class I, Class II, and Class III Saudi subjects. Eur J Orthod 2007;29:457-63.
14. Hagberg C, Larson O, Milerad J. Incidence of cleft lip and palate and risks of additional malformations. Cleft Palate Craniofac $\mathrm{J}$ 1998;35:40-5.

15. Milerad J, Larson O, Hagberg C, Ideberg M. Associated malformations in infants with cleft lip and palate: a prospective, population-based study. Pediatrics 1997;100:180-6.

16. Tanaka SA, Mahabir RC, Jupiter DC, Menezes JM. Updating the epidemiology of cleft lip with or without cleft palate. Plast Reconstr Surg 2012;129:511e-8e.

17. Parker SE, Mai CT, Canfield MA, Rickard R, Wang Y, Meyer RE, et al. Updated National Birth Prevalence estimates for selected birth defects in the United States, 2004-2006. Birth Defects Res A Clin Mol Teratol 2010;88:1008-16.

18. Lopez-Gimenez A, Silvestre-Rangil J, Silvestre FJ, ParedesGallardo V. Craniofacial cephalometric morphologies in different cleft types: a retrospective cross-sectional study of 212 patients. Oral Radiol 2018;34:127-35.

19. Shetye PR, Evans CA. Midfacial morphology in adult unoperated complete unilateral cleft lip and palate patients. Angle Orthod 2006;76:810-6.

20. Ozturk $Y$, Cura N. Examination of craniofacial morphology in children with unilateral cleft lip and palate. Cleft Palate Craniofac $\mathrm{J}$ 1996;33:32-6.

21. Lin Y, Fu Z, Ma L, Li W. Cone-beam computed tomographysynthesized cephalometric study of operated unilateral cleft lip and palate and noncleft children with Class III skeletal relationship. Am J Orthod Dentofacial Orthop 2016;150:802-10.

22. Harris EF. Size and form of the cranial base in isolated cleft lip and palate. Cleft Palate Craniofac J 1993;30:170-4

23. Tinano MM, Martins MA, Bendo CB, Mazzieiro E. Base of the skull morphology and Class III malocclusion in patients with unilateral cleft lip and palate. Dental Press J Orthod 2015;20:79-84.

24. Alpagan Ozdemir S, Esenlik E. Three-dimensional soft-tissue evaluation in patients with cleft lip and palate. Med Sci Monit 2018;24:8608-20.

25. Silverman FN. Roentgen standards fo-size of the pituitary fossa from infancy through adolescence. Am J Roentgenol Radium Ther Nucl Med 1957;78:451-60.

26. Axelsson S, Storhaug K, Kjaer I. Post-natal size and morphology of the sella turcica. Longitudinal cephalometric standards for Norwegians between 6 and 21 years of age. Eur J Orthod 2004;26:597-604.

27. Dhopatkar A, Bhatia S, Rock P. An investigation into the relationship between the cranial base angle and malocclusion. Angle Orthod 2002;72:456-63.

28. Nie $X$. Cranial base in craniofacial development: developmental features, influence on facial growth, anomaly, and molecular basis. Acta Odontol Scand 2005;63:127-35.

29. Sonnesen L, Kjaer I. Cervical column morphology in patients with skeletal Class III malocclusion and mandibular overjet. Am J Orthod Dentofacial Orthop 2007;132:427.e7-12.

30. Singh GD. Morphologic determinants in the etiology of class III malocclusions: a review. Clin Anat 1999;12:382-405.

31. Hong SX, Yi CK. A classification and characterization of skeletal class III malocclusion on etio-pathogenic basis. Int J Oral Maxillofac Surg 2001;30:264-71.

32. Bui C, King T, Proffit W, Frazier-Bowers S. Phenotypic characterization of Class III patients. Angle Orthod 2006;76:564-9.

33. Goyenc YB, Gurel HG, Memili B. Craniofacial morphology in children with operated complete unilateral cleft lip and palate. J Craniofac Surg 2008;19:1396-401.

34. Canıgür Bavbek N. Sella tursika: Gelişimi, boyutları, morfolojisi ve patolojileri Atatürk Üniv Diş Hek Fak Derg 2016;26 Suppl 16:99-107.

35. Halicioglu K, Yolcu G, Yavuz İ. Sella Tursikanin köprülenmesi ve boyutlari ile iskeletsel anomaliler arasındaki ilişki. Atatürk Üniv Diş Hek Fak Derg 2009;19:177-80.

36. Preston CB. Pituitary fossa size and facial type. Am J Orthod 
1979;75:259-63.

37. Shah MB, Bashir U, llyas T. The shape and size of the sella turcica in skeletal Class I, II and III in patients presenting at Islamic International Dental Hospital, Islamabad. Pakistan Oral \& Dental J 2011;31:104-10.

38. Alkofide EA. Sella turcica morphology and dimensions in cleft subjects. Cleft Palate Craniofac J 2008;45:647-53.

39. Sundareswaran S, Nipun CA. Bridging the gap: Sella turcica in unilateral cleft lip and palate patients. Cleft Palate Craniofac J 2015;52:597-604

\section{Tek taraflı dudak ve damak yarığı görülen bireylerde kraniyal kaide ve sella tursika morfolojisinin değerlendirilmesi}

\section{ÖZET}

AMAÇ: Bu çalışmanın amacı, tek taraflı dudak damak yarıklı bireylerde (TDDY), kraniyal kaide ve sella tursikanın boyutlarını ve morfolojisini, maksiller yetersizliğe bağlı Sınıf III anomali gösteren bireyler (CL3) ve normal sınıf I kraniyofasiyal yapıya sahip bireyler (CL1) ile karşılaştırmaktır.

GEREÇ VE YöNTEM: Bu retrospektif çalışma, TDDY (10 kız, 4 erkek; $12.05 \pm 1.14$ yıl), CL3 (10 kı, 5 erkek; $11.73 \pm 0.89$ yıl) ve CL1 (10 kız, 5 erkek; $13.11 \pm 1.11$ yıl) hasta gruplarına ait lateral sefalometrik radyografiler üzerinde yapıldı. Sella tursika ve kraniyal kaideye ait açısal ve doğrusal ölçümler radyografilere ait çizimler üzerinde yapıldı. Gruplar-arası karşılaştırmalarda tek yönlü ANOVA ve Tukey testi veya Bonferroni düzeltmesi ile Kruskal-Wallis testi kullanıldı $(p<0.05)$; korelasyonlar için ise Spearman korelasyon analizi kullanıldı $(p<0.01)$.

BULGULAR: Maksillanın efektif boyutu (Co-A) TDDY $(p=0.035)$ ve CL3 $(p=0.001)$ gruplarında CL1'e göre azalmış bulundu. Toplam kraniyal uzunluk (Ba-N), TDDY grubunda CL3'e $(p=0.012)$ ve CL1'e $(p=0.016)$ göre artmış bulundu. Kraniyal kaide açıSı $\left(\mathrm{N}-\mathrm{S}-\mathrm{Ar} \mathrm{r}^{\circ}\right), \mathrm{CL} 3$ grubunda TDDY $(\mathrm{p}=0.001)$ ve CL1'e ( $p=0.009)$ göre daha azdı. Ba-N $(p=0.003)$ ve ön kafa kaidesi uzunluğu ( $\mathrm{S}-\mathrm{N})(\mathrm{p}=0.000)$ ile Co-A arasında ve arka kafa kaidesi uzunluğu (S-Ba) ile ramus yüksekliği (Ar-Go) $(p=0.001)$ arasında pozitif korelasyonlar bulundu. Sella tursikanın çapının CL1 grubunda CL3'e göre daha fazla olduğu görüldü $(p=0.025)$. Sella tursikaya ait morfolojik varyasyonlar TDDY grubunda kontrol gruplarına göre daha yüksek orandaydı (\%71.4).

Sonuç: TDDY grubunda maksiller yetersizliğe bağlı bir sınıf III maloklüzyon eğilimi olsa da, Sınıf III bireylerde görülen karakteristik kraniyal kaidedenin artmış fleksiyonu, TDDY grubunda görülmedi. Sella tursikanın boyutları TDDY ve CL3 varlığında önemli bir değişim göstermezken morfolojik varyasyonların TDDY grubunda daha fazla olduğu izlendi.

Anahtar Kelimeler: Kafa tabanı; maloklüzyon, Angle sınıf 3; sella tursika; yarık damak; yarık dudak 